\title{
MODELOVÉ REGIONY A MOŽNOSTI JEJICH VYUŽITÍ PŘI HODNOCENÍ REGIONÁLNÍCH DISPARIT ${ }^{1}$
}

\author{
Pavel Tuleja
}

\section{Klíčová slova:}

disparita, indikátor, kvalita života, modelový region, region s všestrannými podmínkami pro život, sociální péče

\section{Key words:}

disparity, an integrated indicator, quality of life model region, the region with versatile living conditions, social care

\begin{abstract}
Abstrakt
V rámci výzkumného projektu „WD-55-07-1: Regionální disparity v územním rozvoji ČR jejich vznik, identifikace a eliminace“, který jsme řešili v průběhu předchozích tří let, jsme svou pozornost zaměřili jak na vlastní definici regionálních disparit, tak na nalezení vhodných metod, které by byly využitelné při měření meziregionálních rozdílností. V průběhu uplynulých tř́ let jsme $\mathrm{v}$ rámci našeho výzkumu dospěli $\mathrm{k}$ závěru, že k hodnocení regionálních disparit můžeme využít dva základní přístupy. Jednou z možností je disparity prezentovat $\mathrm{z}$ věcného hlediska, $\mathrm{k}$ čemuž slouží námi navržené integrované indikátory, jimž jsme se věnovali např́iklad ve stati „Praktická aplikace metod hodnocení regionálních disparit“, jež byla publikována v předchozím čísle Acta academica karviniensis. Druhou variantou je zhodnotit meziregionální rozdíly z čistě uživatelského hlediska, kdy je využit vyšší stupeň agregace, díky čemuž následně vznikají specifické modelové regiony, jež nám umožní hodnotit jednotlivé kraje s větší komplexností, než je tomu v případě integrovaných indikátorů. Tento druhý variantní přístup k hodnocení regionálních disparit pak zachycuje stat' „Modelové regiony a možnosti jejich využití při hodnocení regionálních disparit“, v jejímž rámci jsou představeny jak námi navržené typy modelových regionů, tak jejich praktická ukázka využití, a to na př́ḱladu regionu s všestrannými podmínkami pro život.
\end{abstract}

\begin{abstract}
Within the research project "WD-55-07-1: Regional Disparities in the Land Development of the Czech Republic - Their Origin, Identification And Elimination", we deal with in the past three years, we focused our attention on how their own definition of regional disparities and to find appropriate methods that would be useful in measuring interregional differences. During the past three years, we have our research concluded that the assessment of regional disparities, we can use two basic approaches. One possibility is the disparities present in a material respect, which is our proposed integrated indicators, which we addressed for example in the essay "Practical Application of Methods for Assessment of Regional Disparities", which was published in the previous issue of Acta Academica karviniensis. Another option is to assess interregional differences from a purely user point of view, the use of a higher degree of aggregation, making it subsequently formed model specific regions, enabling us to evaluate each county with more complexity than is the case with integrated indicators. This second alternative approach to the assessment of regional disparities records then become a "Model Regions and Their Possible Use in the Evaluation of Regional Disparities, in which they are
\end{abstract}

\footnotetext{
${ }^{1}$ Článek vznikl díky finanční podpoře MMR ČR v rámci projektu WD-55-07-1: Regionální disparity v územním rozvoji ČR - jejich vznik, identifikace a eliminace
} 
presented as types of model proposed by us region and demonstration of their practical use, and the example of the region with versatile living conditions.

\section{Úvod}

Někteří autoři publikující v oblasti regionální ekonomie dospívají k závěru, z nějž vyplývá, že regionální disparity lze označit za jev, který je vhodné identifikovat a hodnotit pouze tehdy, pokud bude mít pohled na jednotlivé rozdílnosti ve vývoji vybraných regionů multidisciplinární charakter. Přijmeme-li tuto tezi za vlastní, pak narazíme na několik zásadních problémů, k nimž patří nejen identifikace obsahu a rozsahu meziregionálních rozdílů, ale také volba vhodných metod a technik výzkumu. Tyto problémy jsou jednotlivými výzkumnými týmy zpravidla řešeny pomocí důkladné analýzy ekonomické, sociální i prostorové dimenze příslušných regionů a následného výběru indikátorů, s jejichž pomocí lze nejlépe zhodnotit příslušné meziregionální rozdíly. K tomuto přístupu se přiklonil i náš tým v rámci řešení projektu „WD-55-07-1: Regionální disparity v územním rozvoji ČR - jejich vznik, identifikace a eliminace“, přičemž výsledkem tohoto přístupu byl návrh několika typů modelových regionů. Cílem této stati je tyto regiony představit a na praktickém př́kladu také ukázat možnosti jejich využití.

Po důkladné analýze hospodářského a sociálního potenciálu jednotlivých krajů a zmapování stávajících pohledů na modelové regiony dospěl náš řešitelský tým k názoru, že pro potřeby měření meziregionálních rozdílů se jeví jako vhodné navrhnout sedm základních typů modelových regionů, jimiž jsou ekonomicky zaostávající region, region poznamenaný průmyslovým úpadkem či recesí, venkovský region, ekonomicky výkonný region, region s všestrannými podmínkami pro život, region s vysoce rozvinutými sociálními službami a vysoce inovující region. Otázkou zůstává, jak jsou tyto regiony definovány a jak je můžeme využít při hodnocení meziregionálních rozdílů. Odpověd’ na tuto otázku dává následující stat', $\mathrm{v}$ jejímž průběhu se nejprve zaměříme na deskripci všech sedmi výše uvedených modelových regionů a následně na konkrétním příkladu regionu s všestrannými podmínkami pro život ukážeme, jak lze pomocí těchto modelových regionů analyzovat konkrétní oblast, v níž se s větší či menší mírou projevují regionální disparity.

\section{Regionální disparity a modelové regiony}

Pod pojmem regionální disparita rozumíme rozdílnost či také nerovnost znaků, jevů či procesů, které mají zcela jednoznačné umístění a jež se vyskytují alespoň ve dvou entitách př́islušné územní struktury ${ }^{2}$. Jak je z této definice zrrejmé, regionální disparity chápeme jako rozdílnosti, které jsou výsledkem přirozeného vývoje reálně fungující ekonomiky. Dá se tedy říci, že do této skupiny zcela logicky patří jak meziregionální nerovnosti, které jsou z pohledu jednotlivých nositelů hospodářsko-politických rozhodnutí považovány za zcela nežádoucí, což se následně projevuje ve snahách o jejich zmírnění či úplné odstranění, tak disparity, jež lze označit jako neodstranitelné či dokonce žádoucí, z čehož vyplývá, že v jejich případě nositelé hospodářské politiky neprojevují žádnou iniciativu, která by vedla k jejich zmírnění či úplnému odstranění.

Vyjdeme-li z výše uvedeného, pak můžeme konstatovat, že v našem pojetí jsou regionální disparity určitým fenomén, jehož identifikace a následné hodnocení má racionální smysl pouze tehdy, pokud je na rozdílnosti ve vývoji jednotlivých regionů nahlíženo nejen optikou ekonomických, ale také ostatních vědních disciplín. Tento multidisciplinární pohled na

\footnotetext{
${ }^{2}$ Blíže k této problematice Kutscherauer, A. a kol. (2008).
} 
problematiku regionálních disparit má však jeden zásadní problém, jímž je potřeba zcela jednoznačně identifikovat obsah a rozsah meziregionálních rozdílů, a to pomocí různých metod a technik výzkumu, jež jsou k tomuto účelu jednotlivými vědními disciplínami využívány. Vzhledem k tomu, že tyto metody mají jak kvantitativní, tak kvalitativní charakter, narážíme při jejich aktivním použití na celou řadu problémů, které jsou spojené jak se souměřitelností finálních výsledků, tak s obsahovou interpretací vzájemných kauzálních souvislostí vývoje zvolených kvantitativních a kvalitativních ukazatelů. Pro řešení tohoto problému je zpravidla jednotlivými autory navrhováno, aby před vlastním hodnocení regionálních disparit byla výzkumným týmem důkladně analyzována ekonomicko-prostorová a sociálně-prostorová dimenze sledovaných regionů a na jejím základě byl následně proveden konkrétní výběr indikátorů, s jejichž pomocí bude možno důkladně zhodnotit meziregionální rozdíly ${ }^{3}$. Tento př́istup $\mathrm{k}$ hodnocení regionálních disparit zvolil také náš výzkumný tým, přičemž výsledkem těchto snah byl návrh několika typů modelových regionů, jimž budeme věnovat svou pozornost v následující části této stati.

\subsection{Charakteristika modelových regionů}

V rámci námi realizovaného výzkumu jsme si modelový region definovali jako vysoce strukturovanou a složitou sociálně-ekonomickou entitu, která je vymezena zcela jednoznačnými kritérii, jež odborné veřejnosti umožní příslušné regiony dále rozčlenit či typizovat. Mezi tato měřítka jsme pak zařadili zejména kritéria socio-kulturní, ekonomická, územní a kritéria spojená s kvalitou životního prostředí, přičemž jsme neopomněli brát v potaz také charakter vývoje př́íslušného regionu. Při vlastním vymezení jednotlivých regionů jsme svou inspiraci hledali v řadě odborných studií, $\mathrm{z}$ nichž $\mathrm{k}$ nejvýznamnějším můžeme zařadit práce publikované Jeffreyem Harropem, Milanem Viturkou a Viktorií Klímovou či kolektivem autorů soustředěných kolem Věry Czesané. Než se tedy budeme věnovat našim vlastním návrhům modelových regionů, jeví se nám jako vhodné stručně shrnout závěry, k nimž jsme v průběhu studia výše uvedených publikací dospěli.

Podíváme-li se na prrístup jednotlivých autorů ke konstrukci modelových regionů detailněji, pak dospějeme $\mathrm{k}$ závěru, že většina z nich při sestavování jednotlivých modelových typů regionů vychází z ekonomického potenciálu zkoumané entity. Do této skupiny můžeme zařadit např. členění, jež ve své studii „Structural Funding a Employment in the European Union: Financing the Path to Integration" uvedl na konci minulého století Jeffrey Harrop, jenž ve své typologii použil členění regionů na nedostatečně rozvinuté periferní regiony, upadající a staré industriální regiony, centrální regiony a rychle se rozvíjející regiony ${ }^{4}$. S poněkud jiným pohledem na rozdělení regionů přišla Věra Czesaná (2009), která společně se svými kolegy v rámci publikace „Ročenka konkurenceschopnosti České republiky v letech 2007-2008“ rozčlenila jednotlivé regiony do dvou základních skupin, z nichž v prvním případě hrály rozhodující roli výkonnost a inovace, kdežto ve druhém případě byl podstatný vlastní charakter regionu. V rámci těchto skupin autoři jednotlivé modelové regiony dále rozčlenili na ekonomicky výkonné vysoce inovující regiony, ekonomicky výkonné inovující regiony, inovující regiony a ekonomicky a inovačně zaostávající regiony, to $\mathrm{v}$ případě první skupiny, a na regiony metropolitní, adaptabilní, periferní a staré průmyslové, přičemž toto členění využívají v okamžiku, kdy za rozhodující považují charakter regionu. Se zcela odlišným př́stupem se setkáváme u Milana Viturky a Viktorie Klímové, kteří regiony člení bud’to dle kritéria interaktivnosti, $\mathrm{v}$ jehož př́ípadě berou v potaz integrační potenciál a konkurenční

\footnotetext{
${ }^{3}$ Blíže k této problematice Gajdoš, Pašiak (2006).

${ }^{4}$ Blíže k této problematice Harrop (1996).
} 
pozici, nebo pomocí inovačních profilů, kde hlavní roli hrají pozice v inovačním podnikání a specializace inovačních firem ${ }^{5}$.

Kromě výše uvedených autorů se s vlastní typologií regionů můžeme setkat také v oficiálních materiálech, jež jsou publikovány bud'to českou vládou nebo Evropskou komisí. Z pohledu české vlády, která vychází ze znění zákona č. 248/2000 Sb. o podpoře regionálního rozvoje, lze regiony rozdělit do čtyř skupin, a to na regiony strukturálně postižené, hospodářsky slabé, venkovské regiony a ostatní regiony, v jejichž případě je žádoucí podpora ze strany státu. Do jisté míry podobnou typologii regionů využívá také Evropské komise, která na základě zcela jednoznačně stanovených kritérií člení jednotlivé územní celky Evropské unie na regiony zaostalé, regiony poznamenané průmyslovým úpadkem či ekonomickou recesí, příhraniční regiony, regiony s urbanistickými problémy a venkovské regiony. Podrobnější srovnání všech výše uvedených prrístupu naleznete v tabulce 1 .

\section{Tabulka 1 - Komparace námi vybraných přístupů k typologii modelových regionů}

\begin{tabular}{|c|c|c|c|c|}
\hline $\begin{array}{l}\text { typ modelového } \\
\text { regionu }\end{array}$ & J. Harrop & V. Czesaná a kol. & zákon č. 248/2000 & Evropská komise \\
\hline zaostalý region & $\begin{array}{l}\text { nedostat. rozvinutý } \\
\text { perif. region }\end{array}$ & $\begin{array}{l}\text { ekonom. a inovač. } \\
\text { zaost. region }\end{array}$ & $\begin{array}{l}\text { hospod. slabý } \\
\text { region }\end{array}$ & zaostalý region \\
\hline $\begin{array}{l}\text { region poznam. } \\
\text { prům. úpadkem či } \\
\text { recesí }\end{array}$ & $\begin{array}{l}\text { upadající a starý } \\
\text { průmysl. region }\end{array}$ & $\begin{array}{l}\text { ekonom. a inovač. } \\
\text { zaost. starý prům. } \\
\text { region }\end{array}$ & $\begin{array}{c}\text { strukturálně } \\
\text { postižený region }\end{array}$ & $\begin{array}{l}\text { region poznam. } \\
\text { prům. úpadkem či } \\
\text { recesí }\end{array}$ \\
\hline periferní region & $\begin{array}{c}\text { nedostat. rozvinutý } \\
\text { perif. region }\end{array}$ & periferní region & ostatní regiony & příhraniční region \\
\hline příhraniční region & $\begin{array}{c}\text { nedostat. rozvinutý } \\
\text { perif. region }\end{array}$ & periferní region & ostatní regiony & příhraniční region \\
\hline venkovský region & ne & ne & venkovský region & venkovský region \\
\hline $\begin{array}{l}\text { region s urbanist. } \\
\text { problémy }\end{array}$ & centrální region & metropolitní region & ne & $\begin{array}{l}\text { region s urbanist. } \\
\text { problémy }\end{array}$ \\
\hline $\begin{array}{l}\text { ekonom. vyspělý } \\
\text { (prosper.) region }\end{array}$ & $\begin{array}{l}\text { rychle se rozvíjející } \\
\text { region }\end{array}$ & $\begin{array}{c}\text { ekonom. výkonný } \\
\text { vysoce inov. region }\end{array}$ & ne & ne \\
\hline region pro život & ne & ne & ne & ne \\
\hline inovativní region & ne & $\begin{array}{c}\text { ekonom. výkonný } \\
\text { vysoce inov. region }\end{array}$ & ne & ne \\
\hline
\end{tabular}

Pramen: vlastní zpracování řě̌itelů projektu

\section{Modelové regiony pro hodnocení regionálních disparit}

Vzhledem k tomu, že ani jeden z výše uvedených př́stupů zcela neodpovídal našemu pohledu na problematiku hodnocení regionálních disparit, dospěli jsme v průběhu námi realizovaného výzkumu k závěru, že nejvhodnějším řešením bude navrhnout vlastní typologii modelových regionů, která by zcela odpovídala našim požadavkům a stala se tak nedílnou součástí námi navržených metod hodnocení meziregionálních rozdílů. Při konstrukci této typologie jsme za východisko považovali hospodářský a sociální potenciál regionu, v jehož rámci jsem ze skupiny předem vybraných indikátorů, zvolili takové ukazatele, které, dle našeho názoru, případnému uživateli této typologie umožní zvýšit si svůj stávající stav poznání a motivují jej k realizaci určité konkrétní činnosti, a to tak, že jeho rozhodnutí budou mít nejen operativní, krátkodobý, ale také strategický, dlouhodobý, charakter. Následnou agregací těchto ukazatelů do větších bloků jsme pak ve finále získali relativně autonomní celky, tj. vlastní modelové regiony, jež mohou být využívány jak nositeli hospodářsko-politických rozhodnutí, tak představiteli jednotlivých municipalit či analytickými pracovníky. Konkrétně se pak jedná o sedm základních typů regionů:

\footnotetext{
${ }^{5}$ Blíže k této problematice Viturka (2007) a Viturka, Klímová (2006).
} 
- ekonomicky zaostávající region,

- region poznamenaný průmyslovým úpadkem či recesí,

- venkovský region,

- ekonomicky výkonný region,

- region s všestrannými podmínkami pro život,

- region s vysoce rozvinutými sociálními službami

- a vysoce inovující region.

\section{Ekonomicky zaostávající region}

Za ekonomicky zaostávající regiony považujeme oblasti, pro něž je charakteristická jak nízká ekonomická výkonnost, tak nepříznivá struktura ekonomiky, jež je dána zejména nestandardně vysokým podílem sekundární sféry na celkové zaměstnanosti v regionu. Pro tyto regiony je také typická vysoká míra nezaměstnanosti, což se následně odráží nejen v poměrně vysokém podílu obyvatel, jejichž čistý př́ijem se nachází pod úrovní životního minima, ale také v nízkém disponibilním důchodu domácností. Nízké př́ijmy obyvatel regionu pak zpravidla vedou k odlivu pracovní síly z kraje, což se projevuje zejména v podílu vysokoškolsky vzdělaných obyvatel na celkovém počtu zaměstnaných osob v regionu. Z hlediska produkční sféry se tyto regiony vyznačují nejen nízkým podílem registrovaných ekonomických subjektů na celkovém počtu obyvatel, ale také nízkým podílem inovujících podniků na celkovém počtu firem působících v regionu.

Na základě výše uvedené deskripce, jsme následně dospěli k závěru, z nějž vyplývá, že ekonomicky zaostávající region lze nejlépe popsat pomocí následujících indikátorů:

- hrubý domácí produkt na obyvatele,

- hrubá přidaná hodnota na jednoho zaměstnance,

- čistý disponibilní důchod domácností na jednoho obyvatele,

- podíl domácností s čistým měsíčním př́ijmem pod hranicí životního minima na celkovém počtu domácností,

- podíl zaměstnaných v sekundární sféře,

- podíl vysokoškolsky vzdělaných zaměstnaných ve věkové skupině 15 let a starší,

- míra registrované nezaměstnanosti,

- ekonomické subjekty s 50 a více zaměstnanci na 1 tis. obyvatel,

- ekonomické subjekty s 1.000 a více zaměstnanci

- a podíl inovujících podniků na celkovém počtu podniků v regionu.

\section{Region poznamenaný průmyslovým úpadkem či recesí}

Podobně jako $\mathrm{v}$ předchozím př́ípadě, také pro tento region jsou typickými rysy nízká ekonomická výkonnost, nestandardně vysoký podíl sekundární sféry na celkové zaměstnanosti regionu, vysoká míra registrované nezaměstnanosti, nízké disponibilní důchody domácností a vysoký podíl obyvatel s čistým př́ijmem pod úrovní životního minima. Kromě těchto charakteristických znaků je pro kraj poznamenaný průmyslovým úpadkem typický také relativně vysoký podíl produkce v sekundární sféře na celkové produkci, vysoká neuspokojená nabídka práce a poměrně velká rozloha průmyslových ploch, jež jsou dotčeny předchozím používáním a v současnosti vyžadují určitou intervenci, která umožní jejich budoucí využívání. 
$\mathrm{V}$ př́ípadě tohoto regionu jsme dospěli $\mathrm{k}$ závěru, že $\mathrm{k}$ jeho deskripci se nejvíce hodí následující indikátory:

- hrubý domácí produkt na obyvatele,

- podíl hrubé přidané hodnoty vyprodukované v sekundární sféře na celkové HPH kraje,

- čistý disponibilní důchod domácností na jednoho obyvatele,

- podíl domácností s čistým měsíčním př́ijmem pod hranicí životního minima na celkovém počtu domácností,

- podíl zaměstnaných v sekundární sfére,

- míra registrované nezaměstnanosti,

- počet uchazečů na jedno volné pracovní místo

- a rozloha brownfields.

\section{Venkovský region}

Třetím námi navrženým typem modelového regionu je venkovský region, pro nějž je charakteristická nejen nízká ekonomická výkonnost, ale také nestandardně vysoké podíly primárního sektoru jak na hrubé přidané hodnotě, tak na zaměstnanosti. Také v tomto případě se dá očekávat, že v daném regionu bude dosahována relativně vysoká míra registrované nezaměstnanosti, nízká hodnota čisté ročního disponibilního důchodu domácností, region se bude vyznačovat poměrně nízkým podílem jak vysokoškolsky vzdělaných obyvatel na celkovém počtu zaměstnaných osob v regionu, tak ekonomických subjektů s 50 a více zaměstnanci. Současně také předpokládáme, že pro venkovské regiony bude typický vysoký podíl zemědělské půdy na celkové rozloze příslušné oblasti.

Vyjdeme-li z tohoto popisu regionu, pak dospějeme k závěru, že tento region nejlépe charakterizují tyto indikátory:

- hrubý domácí produkt na obyvatele,

- podíl hrubé prridané hodnoty vyprodukované v primární sféře na celkové HPH kraje,

- čistý disponibilní důchod domácností na jednoho obyvatele,

- podíl zaměstnaných v primární sféře,

- podíl vysokoškolsky vzdělaných zaměstnaných ve věkové skupině 15 let a starší,

- míra registrované nezaměstnanosti,

- ekonomické subjekty s 50 a více zaměstnanci na 1 tis. obyvatel

- a podíl zemědělské půdy na celkové rozloze regionu.

\section{Ekonomicky výkonný region}

Ekonomicky výkonný region je určitým opakem ekonomicky zaostávajícího regionu, z čehož vyplývá, že v tomto případě je pro danou oblast charakteristická nejen vysoká ekonomická výkonnost, ale tato oblast se vyznačuje také odpovídající strukturou ekonomiky, tj. strukturou v níž podíl sekundárního sektoru na celkové HPH odpovídá či se blíží podílům běžným pro standardně fungující tržní ekonomiky. Tyto regiony se pak dále vyznačují nízkou mírou nezaměstnanosti, poměrně malým podílem obyvatel s čistým př́ijmem pod úrovní životního minima a vysokým disponibilním důchodu domácností. Pro dané oblasti je typický př́liv pracovní síly z ostatních krajů, což se nejvýrazněji projevuje na podílu vysokoškolsky vzdělaných obyvatel na celkovém počtu zaměstnaných osob. V oblasti produkční sféry se regiony vyznačují vysokým podílem registrovaných ekonomických subjektů na celkovém počtu obyvatel, ale také vysokým podílem inovujících podniků. 
Ekonomicky výkonné regiony tak, dle našeho názoru, můžeme nejlépe popsat pomocí následujících indikátorů:

- hrubý domácí produkt na obyvatele,

- hrubá přidaná hodnota na jednoho zaměstnance,

- čistý disponibilní důchod domácností na jednoho obyvatele,

- podíl domácností s čistým měsíčním př́ijmem pod hranicí životního minima na celkovém počtu domácností,

- podíl zaměstnaných v sekundární sféře,

- podíl vysokoškolsky vzdělaných zaměstnaných ve věkové skupině 15 let a starší,

- míra registrované nezaměstnanosti,

- ekonomické subjekty s 50 a více zaměstnanci na 1 tis. obyvatel,

- ekonomické subjekty s 1.000 a více zaměstnanci

- a podíl inovujících podniků na celkovém počtu podniků v regionu.

\section{Region s všestrannými podmínkami pro život}

Také region s všestrannými podmínkami pro život je oblastí, v jejímž případě se, podobně jako u ekonomicky výkonného regionu, zaměřujeme spíše na kladné stránky jejího rozvoje. Dá se tedy říci, že mezi typické rysy této oblasti můžeme zařadit vysokou úroveň disponibilního důchodu domácností, nízkou míru dlouhodobé nezaměstnanosti a taktéž vysoký stupeň vzdělanosti obyvatel. Pro region je také charakteristický vysoký standard v oblasti bydlení, kultury, sportu a sociální péče a relativně nízká kriminalita. Jednotlivé oblasti př́slušného kraje jsou velmi dobře dostupné a region se také vyznačuje kvalitním životním prostředím. Také $\mathrm{v}$ tomto případě pak nalezneme celou řadu indikátorů, s jejichž pomocí jsme schopni lépe určit, zda je daný region možno označit jako region s všestrannými podmínkami pro život, či nikoliv. Z těchto indikátorů jsme v námi navržené podobě modelového regionu vybrali 13 základních ukazatelů, jimiž jsou:

- čistý disponibilní důchod domácností na jednoho obyvatele,

- podíl vysokoškolsky vzdělaných zaměstnaných ve věkové skupině 15 let a starší,

- míra dlouhodobé nezaměstnanosti,

- počet míst v zařízeních sociální péče na 10 tis. obyvatel,

- počet veřejných knihoven s pobočkami na 10 tis. obyvatel,

- počet středisek pro volný čas dětí a mládeže na 10 tis. obyvatel,

- počet sportovních zařízení na 10 tis. obyvatel,

- počet zjištěných trestných činů na 1 tis. obyvatel,

- počet osob v trvale obydlených bytech na jednu místnost,

- emise oxidu siřičitého na $\mathrm{km}^{2}$,

- podíl zalesněné plochy na území kraje,

- celková délka silnic a dálnic na $100 \mathrm{~km}^{2}$

- a hustota železničních tratí v km na $100 \mathrm{~km}^{2}$.

\section{Region s vysoce rozvinutými sociálními službami}

K charakteristickým rysům regionu s vysoce rozvinutými sociálními službami řadíme zejména vysokou úroveň těch služeb, které jsou zabezpečovány zařízeními sociální infrastruktury, tj. nemocnicemi a zařízeními sociální péče. Vysoká úroveň sociálních služeb $\mathrm{v}$ těchto regionech by pak měla přispívat nejen ke zkvalitnění životních podmínek obyvatel 
příslušného kraje, ale měla by také vytvářet dostatečné podmínky pro rozvoj lidského potenciálu. Tyto regiony by se tak měly vyznačovat poměrně nízkou úrovní sociální exkluze.

Výše uvedená deskripce nás následně přivedla k závěru, že pro popis tohoto typu regionu se jako nejvhodnější jeví následující indikátory:

- počet lékařů na 10 tis. obyvatel,

- počet lůžek v nemocnicích na 10 tis. obyvatel,

- počet míst $\mathrm{v}$ zařízeních sociální péče na 10 tis. obyvatel,

- a počet zapsaných dětí v mateřských školkách na jednu třídu.

\section{Vysoce inovující region}

Posledním, a to sedmým, námi navrženým modelovým regionem, je vysoce inovující region, mezi jehož hlavní charakteristické rysy můžeme zařadit nadstandardní ekonomickou úroveň, která je navíc podpořena nejen vysokou národohospodářskou produktivitou práce, ale také odpovídající úrovní investičních aktivit. K dalším typickým rysům tohoto regionu pak můžeme zařadit vysoký podíl vysokoškolsky vzdělaných obyvatel na celkovém počtu zaměstnaných osob v regionu, vysoký podíl inovujících podniků a v neposlední řadě také dostatečnou úroveň vědecko-výzkumných aktivit, a to jak z pohledu počtu výzkumníků zapojených do tohoto procesu, tak z pohledu výdajů na výzkum a vývoj.

K popisu vysoce inovujících regionů by tak, dle našeho názoru, měly být využity následující indikátory:

- hrubý domácí produkt na obyvatele,

- tvorba hrubého fixního kapitálu na obyvatele,

- hrubá přidaná hodnota na jednoho zaměstnance,

- podíl vysokoškolsky vzdělaných zaměstnaných ve věkové skupině 15 let a starší,

- výdaje na výzkum a vývoj na jednoho obyvatele,

- počet zaměstnanců ve výzkumu a vývoji na 1 tis. obyvatel

- a podíl inovujících podniků.

\section{Hodnocení regionální disparity pomocí modelových regionů na příkladu regionu s všestrannými podmínkami pro život}

V předchozí části textu jsme definovali jednotlivé typy modelových regionů, které jsou, dle našeho názoru, dobře využitelné při hodnocení regionálních disparit v určité konkrétní oblasti. Vzhledem k tomu, že se jedná o čistě teoretický přístup $\mathrm{k}$ dané problematice, zaměříme se v druhé části této stati na konkrétní způsob jejich využití, a to na př́kladu regionu s všeobecnými podmínkami pro život.

Již na samotném počátku našeho výzkumu jsme v souvislosti s modelovými regiony dospěli k závěru, že ideálním nástrojem pro prezentaci disparit, jež se u těchto regionů projevují, jsou indikátory, $\mathrm{k}$ jejichž výpočtu lze využít bud'to bodovou metodu, nebo metodu normované proměnné 6 . Tyto indikátory, v našem případě indikátor všestranných podmínek pro život, pak považujeme za agregovanou prezentaci disparit z uživatelského pohledu, díky čemuž má příslušný analytik možnost lépe zhodnotit a popsat příslušné meziregionální rozdíly.

\footnotetext{
${ }^{6}$ Podrobněji viz Tuleja (2010).
} 
Vyjdeme-li z výše uvedené definice modelového regionu s všestrannými podmínkami pro život, pak dospějeme k závěru, že tento model zachycuje oblast, která svým obyvatelům poskytuje dobré předpoklady pro kvalitní život, vyznačující se relativně vysokými příjmy, dobrou situací na trhu práce, nadstandardním sociálním, kulturním a sportovním zázemím, nízkou kriminalitou a kvalitní infrastrukturou. Pro deskripci tohoto typu regionu jsme původně vybrali třináct základních indikátorů, které uživatelům umožní zachytit všeobecné předpoklady pro kvalitní život $v$ daném regionu. V tomto okamžiku je však zapotřebí říci, že v námi uvedeném př́íkladu využijeme $\mathrm{z}$ těchto třinácti indikátorů, ukazatelů pouze dvanáct, nebot' $\mathrm{v}$ prrípadě indikátoru počet osob v trvale obydlených bytech na jednu místnost narážíme na jeden ze základních problémů hodnocení regionálních disparit na základě konkrétních statistikou podložených údajů, a to na nedostatek relevantních statistických dat. Vzhledem $\mathrm{k}$ tomu, že $\mathrm{v}$ př́padě výše uvedeného ukazatele byly k dispozici pouze data pro roky 2005, 2007 a 2008, což by nám ve finále umožnilo vypočíst komplexní indikátor pouze pro rok 2005, rozhodli jsme se tento ukazatel do námi vypočteného indikátoru nezařadit. Složení takto upraveného indikátoru je pak zachyceno v tabulce 2, a to včetně jednotlivých vah, které jsme stanovili na základě našeho vlastního expertního odhadu.

Tabulka 2 - Složení upraveného indikátoru všestranných podmínek pro život a hodnota váh jednotlivých ukazatelů

\begin{tabular}{|l|c|}
\hline indikátor & váha \\
\hline čistý disponibilní důchod domácností na jednoho obyvatele & 0,110 \\
\hline podíl vysokoškolsky vzdělaných zaměstnaných ve věkové skupině 15 let a starší & 0,110 \\
\hline míra dlouhodobé nezaměstnanosti & 0,110 \\
\hline počet míst v zařízeních sociální péče na 10 tis. obyvatel & 0,080 \\
\hline počet veřejných knihoven s pobočkami na 10 tis. obyvatel & 0,060 \\
\hline počet středisek pro volný čas dětí a mládeže na 10 tis. obyvatel & 0,070 \\
\hline počet sportovních zařízení na 10 tis. obyvatel & 0,070 \\
\hline počet zjišš̌ných trestných činů na 1 tis. obyvatel & 0,100 \\
\hline emise oxidu siřičitého na km ${ }^{2}$ & 0,110 \\
\hline podíl zalesněné plochy na území kraje & 0,060 \\
\hline celková délka silnic a dálnic na $100 \mathrm{~km}^{2}$ & 0,080 \\
\hline hustota železničních tratí v km na $100 \mathrm{~km}^{2}$ & 0,040 \\
\hline
\end{tabular}

Pramen: vlastní zpracování řešitelů projektu

\subsection{Indikátor všestranných podmínek pro život vypočtený pomocí bodové metody}

Využijeme-li k výpočtu indikátoru všestranných podmínek pro život bodovou metodu, pak přiřadíme $\mathrm{v}$ jednotlivých letech příslušným ukazatelům konkrétní bodovou hodnotu, a to $\mathrm{v}$ závislosti na výši promile, kterou činí hodnota tohoto indikátoru z dřive stanovené kriteriální hodnoty. Takto získané bodové ohodnocení pak pro jednotlivé indikátory a jednotlivé roky zprůměrujeme pomocí váženého průměru, přičemž výsledná hodnota bude hodnotou indikátoru všestranných podmínek pro život ${ }^{7}$. Konkrétní výsledky našich propočtů jsou uvedeny v tabulce 3, v níž jsou jednotlivé kraje uspořádány na základě průměrných hodnot, jichž u daného indikátoru dosáhly v průběhu všech šesti námi analyzovaných let. Pozice jednotlivých krajů $v$ tabulce jsou pak určeny na základě pořadí stanoveného pomocí průměrné bodové hodnoty za roky 2001-2006, přičemž u jednotlivých let je navíc použita metoda semaforu, která má lépe zvýraznit postavení jednotlivých regionů v průběhu času. Změny, k nimž v námi sledovaném období docházelo, jsou následně zachyceny také na obrázku 1.

\footnotetext{
${ }^{7}$ Detailnější popis bodové metody a jejího využití při výpočtu integrovaných indikátorů naleznete ve stati Tuleja (2010) a výzkumné zprávě Tuleja (2009).
} 
Z údajů zobrazených v tabulce 3 je zřejmé, že jednotlivé regiony České republiky lze, z hlediska všestranných podmínek pro život, rozdělit do tří kvalitativních pásem, jež můžeme barevně rozlišit na pásmo zelené, žluté a červené. První, zelené pásmo, zachycuje všechny regiony, které svým obyvatelům $\mathrm{v}$ minulosti vytvářely v podstatě nadstandardní př́edpoklady pro kvalitní způsob života. Do této skupiny řadíme kraj Vysočina, Jihomoravský kraj, Jihočeský kraj, Hl. m. Prahu a v podstatě také kraj Královehradecký. Druhé pásmo regionů, v němž převažuje barva žlutá, popř. oranžová, tvoří kraje Olomoucký, Plzeňský, Zlínský, Liberecký, Pardubický a Středočeský. Poslední, tj. červené pásmo, s nejhoršími podmínkami pro kvalitní život v rámci České republiku je tvořeno krajem Karlovarským, Moravskoslezským a Ústeckým, přičemž v případě těchto regionů platí, že námi vypočtený indikátor se nachází nejen hluboko pod celorepublikovým průměrem, ale také pod hranicí 1.000 bodů, a to $\mathrm{s}$ jedinou malou výjimkou v případě Karlovarského kraje, kde v roce 2001 překročila hodnota indikátoru výše uvedenou kritickou hranici o 6,3 bodu.

Tabulka 3 - Pořadí jednotlivých regionů z hlediska hodnoty indikátoru všestranných podmínek pro život v jednotlivých krajích České republiky v letech 2001-2006 (bodová metoda, vážený průměr)

\begin{tabular}{|l|r|r|r|r|r|r|}
\hline kraj & \multicolumn{1}{|c|}{2001} & \multicolumn{1}{c|}{2002} & \multicolumn{1}{c|}{2003} & \multicolumn{1}{c|}{2004} & \multicolumn{1}{c|}{2005} & \multicolumn{1}{c|}{2006} \\
\hline Vysočina & 1625,8 & 1701,3 & 1680,6 & 1738,1 & 1826,0 & 1861,1 \\
\hline Jihomoravský kraj & 1721,7 & 1677,3 & 1571,6 & 1555,7 & 1520,9 & 1500,9 \\
\hline Jihočeský kraj & 1414,0 & 1418,2 & 1412,3 & 1393,2 & 1360,6 & 1379,2 \\
\hline Hlavní město Praha & 1274,2 & 1333,0 & 1406,4 & 1314,1 & 1349,2 & 1375,3 \\
\hline Královéhradecký kraj & 1354,9 & 1371,5 & 1321,2 & 1297,0 & 1291,8 & 1304,2 \\
\hline Olomoucký kraj & 1245,2 & 1260,3 & 1253,8 & 1267,4 & 1257,3 & 1335,1 \\
\hline Plzeňský kraj & 1248,2 & 1276,2 & 1241,5 & 1248,2 & 1231,1 & 1241,3 \\
\hline Zlínský kraj & 1225,2 & 1239,3 & 1240,6 & 1217,8 & 1252,7 & 1262,2 \\
\hline Liberecký kraj & 1206,4 & 1223,8 & 1214,0 & 1222,8 & 1268,6 & 1278,4 \\
\hline Pardubický kraj & 1177,7 & 1183,0 & 1173,7 & 1191,9 & 1197,3 & 1191,5 \\
\hline Stř́edočeský kraj & 1115,5 & 1134,0 & 1152,8 & 1142,6 & 1175,7 & 1172,7 \\
\hline Karlovarský kraj & 1006,3 & 983,6 & 991,1 & 988,2 & 984,6 & 973,4 \\
\hline Moravskoslezský kraj & 954,8 & 935,3 & 925,1 & 943,2 & 938,5 & 922,3 \\
\hline Ústecký kraj & 852,8 & 850,8 & 835,3 & 840,2 & 832,7 & 837,5 \\
\hline
\end{tabular}

Pramen: vlastní výpočet

Jak je zřejmé, z obrázku 1 po celých šest let se nadstandardními podmínkami pro život vyznačovaly v podstatě pouze dva regiony, a to kraj Vysočina a Jihomoravský kraj. Zatímco u Jihomoravského kraje docházelo v průběhu tohoto období $\mathrm{k}$ jeho konvergenci $\mathrm{k}$ průměru ČR (pokles ze 138,61 \% průměru na 120,84 \% váženého průměru všech čtrnácti regionů ${ }^{8}$ ), v případě kraje Vysočina byl tento vývoj výrazně divergentní, když hodnota příslušného indikátoru vzrostla ze 130,89 \% celorepublikové úrovně v roce 2001 na 149,84 procent této úrovně v posledním roce námi analyzovaného období. $\mathrm{Z}$ tohoto pohledu můžeme tedy říci, že kraj Vysočina je dlouhodobě krajem s nejvšestrannějšími podmínkami pro život.

K podobným závěrům dospějeme také $\mathrm{v}$ okamžiku, kdy svou pozornost zaměříme na regiony s nejhoršími výsledky. Z údajů zobrazených na obrázku 1 vyplývá, že v tomto př́padě budeme hovořit o třech regionech, které dlouhodobě výrazně zaostávají za celorepublikovým

\footnotetext{
${ }^{8}$ Při výpočtu váženého průměru jsme váhu pro jednotlivé kraje stanovili na základě podílu průměrného počtu obyvatel daného regionu na celkovém počtu obyvatel České republiky.
} 
průměrem, přičemž v průběhu námi analyzovaného období byl jejich vývoj také spíše divergentní, o čemž svědčí i námi vypočtené údaje. Nejvýrazněji se pak disparity zvětšily v případě Karlovarského a Moravskoslezského kraje a naopak nejméně u dlouhodobě nejhưře hodnoceného regionu, jimž je kraj Ústecký.

Pokud se zaměříme na dynamiku změn, pak můžeme konstatovat, že kromě již výše uvedeného kraje Vysočina zaznamenaly v oblasti všestranných podmínek pro život pozitivní dynamiku růstu také následující regiony: Hl. m. Praha, kde ve vztahu k celorepublikovému průměru došlo ke zlepšení o 8,14 \%, Olomoucký kraj se zlepšením o 7,24 procentních bodů vůči průměru a dále pak také kraje Liberecký, Středočeský, Zlínský a Pardubický, přičemž ve vztahu k průměrné úrovni všestranných podmínek pro život můžeme za konvergující označit pouze poslední čtyř ze sedmi výše jmenovaných regionů. Zbývající tři regiony tak můžeme označit za kraje, pro něž bylo typické další prohlubování meziregionálních rozdílů.

\section{Obrázek 1 - Vývoj upraveného indikátoru všestranných podmínek pro život v jednotlivých krajích České republiky v letech 2001-2006 (bodová metoda, vážený průměr)}

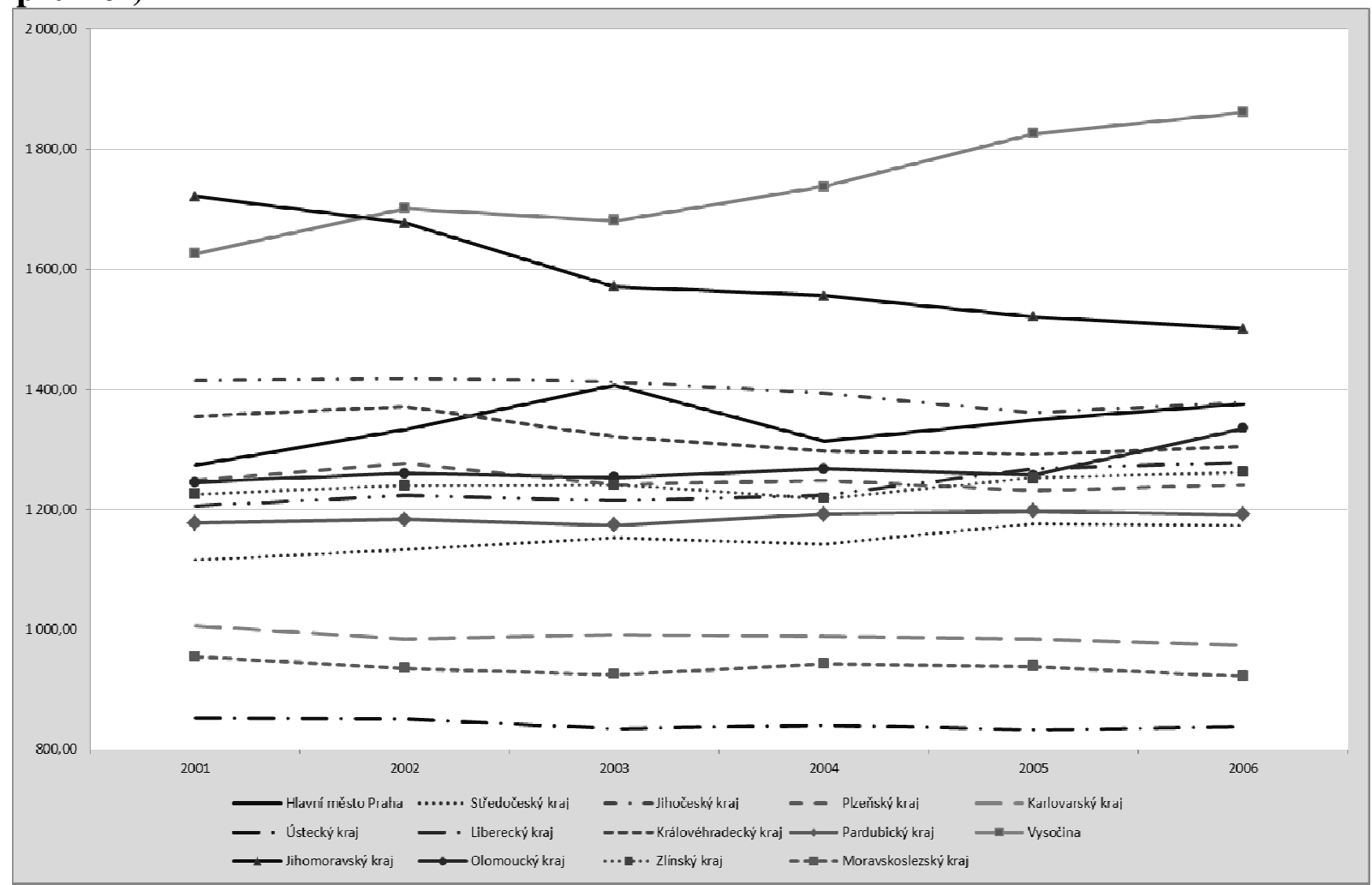

Pramen: vlastní výpočet

Podíváme-li se na dynamiku změn z opačného hlediska, tj. z pohledu negativní dynamiky růstu, pak dospějeme k závěru, že s nejvýraznějším zhoršením kvality života se mezi roky 2001 a 2006 potýkal již výše uvedený Jihomoravský kraj, v jehož prŕípadě lze však tento proces označit spíše za proces konvergence $\mathrm{k}$ celorepublikovému průměru. $\mathrm{S}$ výrazně nižším poklesem se pak setkáváme u kraje Královehradeckého (-4,08 \%), Jihočeského (-2,80\%), Karlovarského (-2,65 \%), Moravskoslezského (-2,62 \%), Ústeckého (-1,23\%) a Plzeňského ($0,56 \%$ ). Zatímco v případě Karlovarského, Moravskoslezského a Ústeckého kraje by se tento proces dal označit jako proces divergence vưči váženému průměru České republiky, v případě zbývajících regionů lze tento proces označit jako proces konvergenční. 


\subsection{Indikátor všestranných podmínek pro život vypočtený pomocí metody normované proměnné}

Druhou z možností, jež se nám nabízí v souvislosti s výpočtem indikátoru všestranných podmínek pro život, je metoda normované proměnné. Pokud při výpočtu využijeme tuto metodu, pak hodnotu indikátoru stanovíme pomocí normované proměnné, kterou vypočteme jako podíl rozdílu mezi kriteriální a skutečnou hodnotou na směrodatné odchylce disponibilního vzorku statistických ukazatelù . Námi stanovené konkrétní hodnoty indikátoru všestranných podmínek pro život vypočteného pomocí této metody jsou uvedeny v tabulce 4, v níž, podobně jako $\mathrm{v}$ předchozím případě, jsou jednotlivé kraje opět uspořádány na základě průměrných hodnot, které tyto regiony dosáhly v průběhu let 2001 až 2006. Také v tomto př́ípadě je využita metoda semaforu, s jejíž pomocí jsme schopni lépe zdůraznit postavení jednotlivých krajů v průběhu času. Průběžné změny v postavení regionů jsou pak zachyceny na obrázku 2.

Tabulka 4 - Pořadí jednotlivých regionů $\mathrm{z}$ hlediska hodnoty upraveného indikátoru všestranných podmínek pro život v jednotlivých krajích České republiky v letech 20012006 (metoda normované proměnné, vážený průměr)

\begin{tabular}{|l|r|r|r|r|r|r|}
\hline kraj & \multicolumn{1}{|c|}{2001} & \multicolumn{1}{c|}{2002} & \multicolumn{1}{c|}{2003} & \multicolumn{1}{c|}{2004} & \multicolumn{1}{c|}{2005} & \multicolumn{1}{c|}{2006} \\
\hline Královéhradecký kraj & 0,332 & 0,328 & 0,326 & 0,317 & 0,248 & 0,279 \\
\hline Pardubický kraj & 0,242 & 0,260 & 0,274 & 0,276 & 0,304 & 0,212 \\
\hline Zlínský kraj & 0,200 & 0,215 & 0,260 & 0,253 & 0,269 & 0,295 \\
\hline Vysočina & 0,205 & 0,231 & 0,230 & 0,213 & 0,197 & 0,164 \\
\hline Jihočeský kraj & 0,153 & 0,185 & 0,165 & 0,148 & 0,084 & 0,101 \\
\hline Olomoucký kraj & 0,037 & 0,032 & 0,036 & 0,165 & 0,142 & 0,255 \\
\hline Plzeňský kraj & 0,125 & 0,174 & 0,105 & 0,118 & 0,060 & 0,047 \\
\hline Liberecký kraj & 0,086 & 0,053 & 0,044 & $-0,002$ & 0,046 & 0,030 \\
\hline Středočeský kraj & $-0,030$ & 0,003 & 0,030 & $-0,017$ & 0,069 & 0,038 \\
\hline Jihomoravský kraj & 0,014 & $-0,005$ & $-0,056$ & $-0,028$ & $-0,068$ & $-0,087$ \\
\hline Karlovarský kraj & $-0,008$ & $-0,058$ & $-0,056$ & $-0,053$ & $-0,085$ & $-0,113$ \\
\hline Moravskoslezský kraj & $-0,265$ & $-0,324$ & $-0,372$ & $-0,343$ & $-0,301$ & $-0,310$ \\
\hline Hlavní město Praha & $-0,591$ & $-0,548$ & $-0,373$ & $-0,475$ & $-0,383$ & $-0,364$ \\
\hline Ústecký kraj & $-0,498$ & $-0,546$ & $-0,614$ & $-0,573$ & $-0,581$ & $-0,545$ \\
\hline
\end{tabular}

Pramen: vlastní výpočet

Vyjdeme-li z údajů v tabulce 4, pak dospějeme k závěru, že jednotlivé regiony lze opět rozdělit do tří kvalitativních pásem, a to na základě převládající barvy z tříbarevné základní škály. Zelené, první, pásmo regionů s velmi dobrými předpoklady pro život v tomto př́ípadě tvoří Královehradecký, Pardubický a Zlínský kraj a dále pak také kraj Vysočina a kraje Jihočeský, Olomoucký a v podstatě také Plzeňský. Součástí druhé pásma regionů s převažující žlutou barvou jsou kraje Liberecký, Středočeský, Jihomoravský a Karlovarský. Převážně červené pásmo regionů s nejhorší kvalitou života v Česku pak tvoří kraj Moravskoslezský, Hl. m. Praha a Ústecký kraj, přičemž průměrná hodnota normované proměnné pro každý z těchto regionů, která se pohybuje v intervalu od $-0,139$ do $-0,559$ jednotek, se nachází hluboko pod celorepublikovým váženým průměrem, který dosahuje výše $-0,064$.

\footnotetext{
${ }^{9}$ Detailnější popis metody normované proměnné a jejího využití při výpočtu integrovaných indikátorů naleznete ve stati Tuleja (2010) a výzkumné zprávě Tuleja (2009).
} 
Z obrázku 2 je zřejmé, že, na rozdíl od bodové metody, v tomto př́ípadě není rozptyl mezi kraji s nadstandardními a průměrnými podmínkami pro život tak jednoznačný a zřetelný. Přesto můžeme říci, že i v tomto př́ípadě nalezneme v této poměrně široké skupině kraje, v jejichž př́padě můžeme v letech 2001-2006 hovořit jak o konvergenčním, tak o divergenčním vývoj ve vztahu $\mathrm{k}$ celorepublikovému průměru. Za výrazně divergentní pak můžeme označit vývoj v kraji Středočeském (růst hodnoty indikátoru z 0,034 na 0,103 ), Zlínském (z 0,265 na 0,359) a zejména pak Olomouckém, v jehož případě vzrostla hodnota indikátoru z 0,101 na konečných 0,319, díky čemuž se Olomoucký kraj posunul z pomyslného osmého místa na místo třetí. Za kraj, jenž je dlouhodobě krajem s nejvšestrannějšími podmínkami pro život, pak můžeme označit kraj Královehradecký, který dosahoval nejlepších výsledků mezi roky 2001 a 2004, přičemž v posledních dvou letech se umístil na třetím, resp. druhém místě.

\section{Obrázek 2 - Vývoj upraveného indikátoru všestranných podmínek pro život v jednotlivých krajích České republiky v letech 2001-2006 (metoda normované proměnné, vážený průměr)}

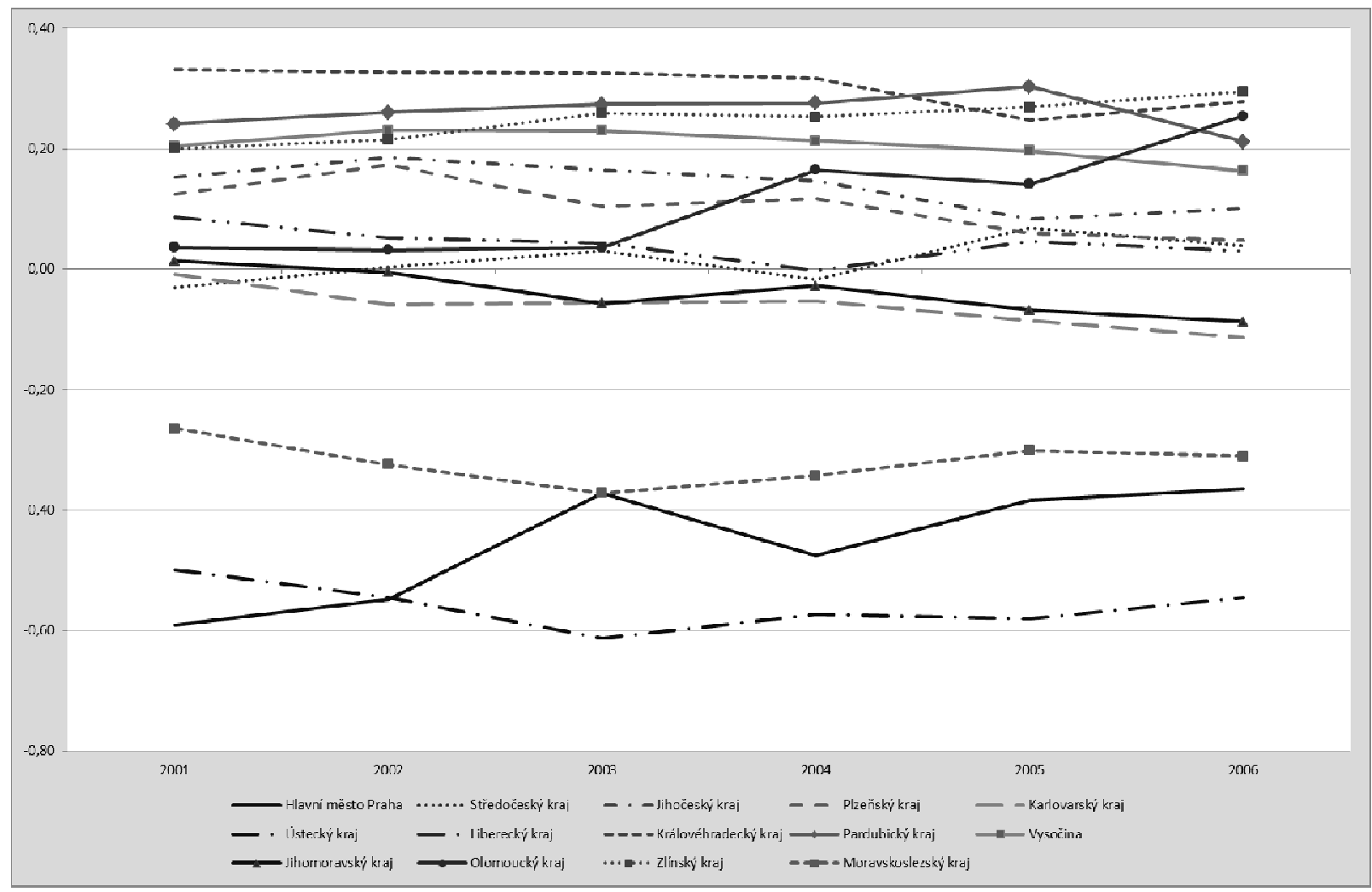

Pramen: vlastní výpočet

Pokud se zaměříme na regiony s nejhorší kvalitou života, zjistíme, že tyto tři regiony dlouhodobě výrazně zaostávají za celorepublikovým průměrem. Navíc je nutno konstatovat, že v případě Moravskoslezského kraje a kraje Ústeckého by se dal dlouhodobý vývoj v těchto regionech označit spíše za divergentní, kdežto u Hl. m. Prahy můžeme hovořit o konvergenci $\mathrm{k}$ celorepublikovému průměru. Tyto naše závěry potvrzují jak údaje zachycené na obrázku 2 , tak v tabulce 4. Za dlouhodobě nejhůřre hodnocený region můžeme označit kraj Ústecký, jež se, s výjimkou roku 2001, dlouhodobě umíst’uje na posledním čtrnáctém místě námi stanoveného pomyslného pořadí krajů České republiky.

Jak je i z výše uvedeného zřejmé, zhlediska dynamiky změn zaznamenaly v námi analyzovaném období pozitivní dynamiku růstu pouze čtyři regiony, a to $\mathrm{Hl}$. m. Praha, 
s největším zlepšením o 0,227 jednotek, Olomoucký kraj, Zlínský kraj a kraj Středočeský. V př́ípadě zbývajících deseti krajů České republiky se střetáváme s opačným vývojem, tj. s negativní dynamikou růstu, přičemž k nejvýraznějšímu zhoršení kvality života došlo v letech 2001-2006 v krajích Karlovarském $(-0,105)$ a Jihomoravském kraji $(-0,101)$, v jejichž případě, podobně jako ve všech zbývajících případech, lze tento proces označit spíše za proces konvergence k celorepublikovému průměru. Ve zbývajících osmi českých regionech se pak setkáváme s menším propadem kvality života, o čemž svědčí také námi vypočtené hodnoty indikátoru všestranných podmínek pro život, které se v daném časovém úseku propadly maximálně o 0,078 a minimálně o 0,030 jednotky.

\section{Závěr}

Tato stat' si kladla za cíl představit soustavu modelových regionů, již lze využít při konkrétním sledování a následném hodnocení regionálních disparit, v okamžiku, kdy je cílem analytika popsat meziregionální rozdíly na vyšším stupni agregace, než je tomu v případě integrovaných indikátorů, o nichž jsme v minulosti hovořili například ve zprávě „Nástroje, indikátory a metody pro sledování a hodnocení regionálních disparit“. V souladu s tímto cílem, jsme tak nejprve zaměřili svou pozornost na deskripce sedmi námi navržených modelových regionů, jimiž jsou ekonomicky zaostávající region, region poznamenaný průmyslovým úpadkem či recesí, venkovský region, ekonomicky výkonný region, region s všestrannými podmínkami pro život, region s vysoce rozvinutými sociálními službami a vysoce inovující region. V rámci této části stati jsme tak postupně stručně popsali všechny výše uvedené modelové regiony, přičemž součástí této deskripce byl také seznam nosných indikátorů, s jejichž pomocí lze stanovit kriteriální hodnoty, které nám umožní jednotlivé typy modelových regionů lépe charakterizovat. Ačkoliv se tento způsob kvantifikace může jevit jako ideální, je v tomto okamžiku zapotřebí poznamenat, že příslušné kriteriální hodnoty považujeme spíše za veličiny mezní, nebot' v reálně fungujícím světě nelze na tyto indikátory pohlížet pouze zjednodušenou optikou, z níž by vyplynulo, že hodnota př́slušného ukazatele je bud'to zcela jednoznačně dobrá, nebo zcela jednoznačně špatná. Jinými slovy řečeno, je nám zcela jasné a zřejmé, že v případě těchto indikátorů působí v realitě určitý synergický efekt.

Konkrétnímu způsobu využití modelových regionů při hodnocení regionálních disparit byla věnována druhá část této stati, v níž jsme se zaměřili na region s všestrannými podmínkami pro život. Pro tento typ modelového regionu jsme následně vypočetli indikátor všestranných podmínek pro život, který považujeme za agregovanou prezentaci disparit z uživatelského hlediska, díky čemuž mají jednotliví analytici možnost lépe zhodnotit a popsat př́islušné meziregionální rozdíly. Jak je i z výše uvedené stati zřejmé, pro vlastní deskripci tohoto typu regionu jsme původně vybrali třináct základních indikátorů, z nichž jsme však, $v$ námi uvedeném příkladu, využili pouze dvanáct ukazatelů, nebot' $\mathrm{v}$ případě ukazatele počet osob $\mathrm{v}$ trvale obydlených bytech na jednu místnost jsme narazili na nedostatek relevantních statistických dat. Vlastní indikátor všestranných podmínek pro život jsme pak vypočetli ve dvou variantních podobách, a to pomocí bodové metody a metody normované proměnné, přičemž v obou případech byly pro získání finální hodnoty použity expertně stanovené váhy.

Vyjdeme-li z výše uvedených výsledků, pak zjistíme, že pomocí obou metod dospějeme $\mathrm{k}$ poněkud odlišným závěrům. Zatímco $\mathrm{v}$ případě bodové metody patřily mezi regiony vyznačující se nadstandardní kvalitou života kraje Vysočina, Jihomoravský a Jihočeský, u metody normované proměnné, to byly kraje Královehradecký, Pardubický a Zlínský. Podíváme-li se podrobněji na pořadí jednotlivých regionů v pomyslném žebřičku krajů, pak zjistíme, že za zcela stabilní můžeme v tomto případě označit pozice pouze u tří regionů, jimiž 
jsou kraje Olomoucký, Plzeňský a Ústecký, které se v obou žebříčcích nacházely na šestém a sedmém, resp. čtrnáctém místě. Za kraje které si v případě metody normované proměnné nejvýrazněji polepšily, pak můžeme označit všechny tři kraje, jež se u této metody umístily na prvních tř̌ech místech. $K$ nejvýraznějšímu zlepšení došlo $v$ tomto případě $u$ kraje Pardubického, jenž si na pomyslném žebříčku polepšil o celých osm míst. Naopak s nejvýraznějším propadem se potkáváme u Hl. m. Prahy a Jihomoravského kraje, což jsou regiony, které se v našem pořadí propadly o devět, resp. osm míst.

Otázkou tedy zůstává, co je prŕícinou těchto rozdílů. Odpověd’ na tuto otázku je poměrně jednoduchá. Nesoulad námi uvedených výsledků vyplývá zejména z odlišného přístupu výše uvedených metod $\mathrm{k}$ výpočtu indikátoru všeobecných podmínek pro život. Zatímco bodová metoda bere $\mathrm{v}$ potaz absolutní proměnlivost ukazatelů, které popisují příslušný modelový region, metoda normované proměnné počítá naopak s proměnlivostí relativní. Vzhledem $\mathrm{k}$ tomu, že z našeho pohledu se při hodnocení meziregionálních rozdílů jeví jako vhodnější relativní proměnlivost ukazatelů, dospěli jsme v konečné fázi výzkumu k závěru, že pro stanovení hodnoty jednotlivých indikátorů popisujících vývoj námi navržených modelových regionů se jeví jako prrijatelnější metoda normované proměnné.

\section{Literatura:}

[1] CZESANÁ, V. A KOL. Ročenka konkurenceschopnosti České republiky 2007-2008. Praha: Linde, 2009.

[2] ČSÚ Krajské ročenky. [on-line] in: http://www.czso.cz/csu/redakce.nsf/i/krajske_rocenky.

[3] ČSÚ Regiony, města, obce. [on-line] in: http://www.czso.cz/csu/redakce.nsf/i/regiony_mesta_obce_souhrn.

[4] ČSUU Veřejná databáze ČSÚ. [on-line] in: http://vdb.czso.cz/vdbvo/uvod.jsp.

[5] GAJDOŠ, P., PAŠIAK, J. Regionálny rozvoj Slovenska z pohl'adu priestorovej sociológie. 1. vyd. Bratislava, SAV, 2006.

[6] HARROP, J. Structural Funding and Employment in the European Union. Financing the Path to Integration. Brookfield, VT: Edward Elgar Publishing, 1996.

[7] KUTSCHERAUER, A. A KOL. Identifikace, klasifikace a hodnocení regionálních disparit. Redakčně upravená roční zpráva 2007. Ostrava: VŠB-TU, 2008. [on-line] in: http://disparity.vsb.cz/vysledky/01_rocni_zprava_2007.pdf.

[8] KUTSCHERAUER, A. A KOL. Nástroje, indikátory a metody pro sledování a hodnocení regionálních disparit. Průběžná výzkumná zpráva. Ostrava: VŠB-TU, 2009. [on-line] in: http://disparity.vsb.cz/vysledky/10_vyzkumna_zprava_3.pdf.

[9] RIS Srovnání kraje s Českou republikou. [on-line] in: http://www.risy.cz/index.php?pid=202\&sid=1288\& mid=1279

[10] RIS Statistická data. [on-line] in: http://www.risy.cz/index.php?pid=508\&language $=\mathrm{CZ} \& \mathrm{kraj}=$.

[11] TULEJA, P. PS2 Aplikace vybraných metod sledování a hodnocení regionálních disparit. Př́padová studie. Ostrava: VŠB-TU, 2009. [on-line] in: http://disparity.vsb.cz/vysledky/14_PS2_Aplikace_vybranych_metod.pdf.

[12] TULEJA, P. Praktická aplikace metod hodnocení regionálních disparit. Acta academica karviniensis, 2010, č. 1. Karviná: SU OPF, 2010. ISSN 1212-415X.

[13] VITURKA, M., KLÍMOVÁ, V. Globálně orientované hodnocení konkurenční pozice krajů ČR. Working paper č. 20/2006. Centrum výzkumu konkurenční schopnosti české ekonomiky. Brno: ESF MU, 2006. 
[14] VITURKA, M. Inovační profily regionů. Working paper č. 11/2007. Centrum výzkumu konkurenční schopnosti české ekonomiky. Brno: ESF MU, 2007.

Klasifikace JEL: R19

Doc. Ing. Pavel Tuleja, Ph.D.

Katedra ekonomie

Obchodně podnikatelská fakulta v Karviné

Slezská univerzita v Opavě

Univerzitní nám. 1934/3

Karviná

tuleja@opf.slu.cz 